Article

\title{
The Impacts of Climate Change on Road Traffic Accidents in Saudi Arabia
}

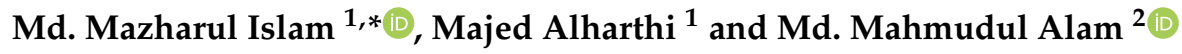 \\ 1 Department of Finance, COB, King Abdulaziz University, Rabigh 21911, Saudi Arabia \\ 2 School of Economics, Finance \& Banking, Universiti Utara Malaysia, Kedah 06010, Malaysia \\ * Correspondence: malislam@kau.edu.sa
}

Received: 15 July 2019; Accepted: 28 August 2019; Published: 30 August 2019

\begin{abstract}
The potential costs of road traffic accidents (RTAs) to society are immense. Yet, no study has attempted to examine the impact of climate change on RTAs in Saudi Arabia, though RTA-leading deaths are very high, and the occurrence of climatic events is very frequent. Therefore, this study aims to assess the impact of climate change on RTAs in Saudi Arabia and to recommend some climate change mitigation and adaptation policies to make roads safe for all. This study employed annual data from 13 regions of Saudi Arabia, from 2003 to 2013. The data were analyzed on the basis of panel regression models-fixed effect, random effect, and the pooled ordinary least square. The findings show that temperature, rainfall, sandstorms, and number of vehicles were statistically and significantly responsible for RTAs in Saudi Arabia in the study period. This study also found that RTAs both inside and outside cities significantly caused injuries, but only RTAs inside cities significantly caused death. Furthermore, the death from RTAs injuries was found to be statistically significant only for motor vehicle accidents. The findings will assist policymakers in taking the right courses of action to mitigate the negative impacts of climate change through understanding climate influence on RTAs.
\end{abstract}

Keywords: road traffic accidents; climate change; injuries; death; mitigation; adaptation; saudi arabia

\section{Introduction}

Road traffic accident (RTA) is defined as a situation caused by the collision of one or more motorized vehicles, such as cars and motorcycles. The consequences of RTAs can be injuries, property damages, deaths, and congestion, disruption, and delays to public transport [1]. According to the World Health Organization [2], road accidents have a high cost in terms of lives, which is equal to about 1.25 million people annually. In addition, the leading cause of death is highway traffic injuries for people who are 15-29 years old, and highway traffic injuries account for more than 300,000 deaths.

Furthermore, RTAs are now in the ninth position when it comes to the cause of death around the world, and are expected to be in the fifth position by 2020 [3]. Moreover, 20-50 million people are injured or disabled globally in road crashes each year [4]. According to the World Bank [5], the highest number of road accidents occurs in low- and middle-income countries (85\%). However, according to the Association for Safe International Road Travel [6], road crashes cost USD \$518 billion globally, costing individual countries $1-2 \%$ of their annual GDP.

WHO [7] reported that safe mobility could reduce RTAs significantly in urban and rural areas. Safe mobility is also highly important as it supports human rights through the protection of other peoples' lives during driving [8]. Moreover, the policies of transportation enhance safe mobility to achieve resilient and sustainable transport control [9]. Therefore, it is important to understand the causes of RTAs in different environmental, socioeconomic, and geographical contexts. 
To reduce RTAs, a large number of research studies have been conducted from an engineering perspective, aiming at improving the vehicle safety systems and designing highways and safety policies [10]. The improvement of highways safety policies, however, is costly; most of the time, the awareness of safety of the drivers varies among people, and it is hard to anticipate that this scenario would change [11]. Previous studies also investigated the influence of various factors on RTAs, such as driver's age, income level, judgment, skill, attention, fatigue, experience, high speed, vehicle's design, manufacture, and maintenance, and environmental conditions, such as lighting, sandstorms, temperature, and precipitations [12-20]. However, out of the many factors that cause RTAs, climatic factors are still the least studied in the literature and therefore need to be addressed. In desert areas, the road environment is generally more vulnerable to increases in the intensity and frequency of hot days, storm activities, and sea level. The impact of climate change on RTAs has not been sufficiently investigated in Middle Eastern countries and, in particular, Saudi Arabia, though the climate of Saudi Arabia is extremely arid, mostly characterized by very low rainfall, very hot and dry summer, and severe evapotranspiration. In addition, as emphasized in Kingdom of Saudi Arabia (KSA) vision 2030 [21], Saudi Arabia is committed to effectively implementing sustainable development and, to this aim, has made steady progress in various sectors and areas. Even though climate change has a significant impact on RTAs [22,23], to date no empirical study has investigated the impact of climate change on RTAs, whose potential costs to society are immense. Therefore, to overcome this literature gap, this study aimed to assess empirically the impact of climate change on the RTAs in Saudi Arabia as an example of climate change-affected arid region.

\section{Literature Review}

\subsection{Road Traffic Accidents in Saudi Arabia}

The literature shows that Saudi Arabia has a high number of road accidents and it is in the second place for road accidents in the Gulf area after Iran [7]. In Saudi Arabia, about 14.8 people died per 1000 vehicles in 2004 compared to the United Kingdom where about 1.5 people died per 1000 vehicles [24]. Furthermore, road accidents were found to be one of the main reasons of death of young adults, accounting for $49 \%$ of death cases for people below 30 years of age $[7,25]$. Moreover, RTAs are considered a threat to health, causing 19 deaths per day and 4 cases of injuries each hour in Saudi Arabia [13]. According to the Saudi Ministry of Interior [26], the number of road traffic accidents was about 550,000 in 2010 and caused roughly 7200 fatalities, implying that there were 20 RTAs for every 1000 people and 1 fatality for every 76 RTAs. Furthermore, RTA is a national problem that adversely affects the economy and societal fabric because the young and economically productive age groups are the most affected by RTAs [27]. The total loss caused by RTAs in Saudi Arabia is recorded to be roughly between $2.2 \%$ and $9 \%$ of the national income compared to that of industrialized countries that is between $1 \%$ and $2 \%$ [28,29]. The annual cost of RTAs has reached $\$ 6$ billion [30]. As a result of the launch of some road safety initiatives, such as strict new punishments for traffic violations, including fines and lengthy prison sentences for causing injury or death, and a crackdown on mobile phone usage, the number of road traffic accidents and injuries has decreased in the last few years [31]. RTAs still cause an average of 20 deaths per day, which is very high by all standards and alarming compared to that of other developed European countries (5.27 death/day) [32]. Most of the road safety initiatives and policies are concerned with institutional reforms and regulation, but the essential issues of climate change mitigation and adaptation are ignored. Therefore, a research investigation conducted in the Saudi Arabian context will help the policymakers to take proper policy actions to reduce RTAs; in addition, the adopted policy might be applicable to similar countries in this region. 


\subsection{Climate Change in Saudi Arabia}

The recent change in the climate of Saudi Arabia indicates that the country is already facing variations of temperatures, dust/sand storms, and rainfalls [33]. Saudi Arabia has a desert climate characterized by extremely high temperatures during the day, a sudden drop in temperature at night, very low annual rainfall, and average humidity. This country has mainly two seasons: summer and winter. The average summer temperature is around $45^{\circ} \mathrm{C}$ (from May to September) for the majority of regions, but it can be as high as $54^{\circ} \mathrm{C}$. In the month of February, March, April, and November, it is neither too cold nor too hot. During peak winter (December to January), the temperature usually drops at night quite rapidly. The annual rainfall is extremely low, especially in the central region. A recent study was conducted by Tarawneh and Chowdhury [34] to examine the trends of climate change in Saudi Arabia and reported an increase in temperature in all regions and a decrease of rainfall in many regions. Almazroui et al. [35] reported that the maximum, mean, and minimum temperatures are increasing significantly at rates of $0.71,0.60$, and $0.48^{\circ} \mathrm{C}$ per decade, respectively. At the same time, Chowdhury and Al-Zahrani [36] predicted an increase in rainfall by $15-25 \mathrm{~mm} /$ year in the central, western, and eastern regions by 2050. Although send/dust storms occur throughout the entire year in Saudi Arabia [37], on the local scale, these events are known to be variable in space and time. For instance, Albugami et al. [37] reported that the eastern and western parts of Saudi Arabia have been experiencing an increase in dust storm events over time, while the occurrence of dust storm events has been decreasing over time in the northern part. Overall, the eastern part of Saudi Arabia experiences the highest number of dust storms per year (i.e., 10 to 60 events), and the west part has fewer dust storm events (i.e., 5 to 15 events per year).

\subsection{Road Traffic Accidents and Climate Change}

Previous studies have investigated the influence of various factors that affect both death and injury severity caused by road traffic accidents. The causes of road crashes can be attributed to human, vehicular, and environmental factors, like becoming busy with different activities while driving (such as usage of mobile phones), failure to see the surroundings of the vehicles [38], negative emotions [39], intake of alcohols, fatigue, medications, drowsiness [20], age, and gender of the drivers [12,13].

Besides the above-mentioned factors, climate change, especially hazardous weather (e.g., wind speed, precipitation, rain, snow, temperature, fog, etc.) can increase the number of road accidents [40-45]. Focusing on the United Kingdom, Edward [43] examined the correlation between weather and road accidents. The results showed a positive and significant association between the indicators of weather and road crashes in the UK, and this result varied concerning seasons and places. Another study was conducted by Edward [44] in England and Wales and concluded that there was a significant relationship between road accidents and hazards of weather.

In addition, Andrey et al. [46] found that the hazards of weather significantly affected the risk of accidents in middle-sized cities of Canada and that the impacts of snowfall were higher than the effects of rainfall. Moreover, Eisenberg and Warner [47] also identified snowfall as a hazardous weather condition. This result is consistent with the findings of Fridstrom [48], who focused on Norway. Furthermore, Musk [49] claimed that the association between the rates of accidents and thick fog was significant and positive. This means that highly poor road visibility results in more RTAs [50,51].

Based on the existing literature, it is observed that the impacts of rainfall on RTA vary widely across the world, but the majority of the studies have proposed that a greater rate of rainfall leads to more accidents [52-59]. For example, Jaroszweski and McNamara [52] reported a positive linear relationship between rainfall amount and the number of road accidents in urban areas of Manchester and Greater London in the UK. In addition, Fridstrom et al. [59] confirmed that rain increased accidents significantly due to loss of vehicle control and lower visibility. Andrey et al. [46] confirmed that an increase in the number of precipitations increased RTAs and injuries by $75 \%$. In contrast, a few studies have reported that there is a negative association between rainfall and RTA, as drivers adjusts their behavior during rainfall $[44,60,61]$. For example, Mondal et al. [60] reported that accident severity 
decreased significantly during rain compared with fine weather in India. They also stated that the extra care of drivers during rainy days, low vehicle speed due to traffic congestion, and runoff effect could be the reasons for this negative relationship between rainfall and RTAs.

According to several researchers, temperature plays a strong role in road accidents, but there is no common definable relationship between temperature and RTAs [62-64]. Some studies have reported that low temperatures are associated with more accidents $[65,66]$; on the other hand, the majority of the studies have reported that high temperatures are the root cause of road accidents, and more time of sunlight leads to more crashes. This means that high temperatures influence RTAs significantly and positively $[57,63,67-70]$.

Only a few studies have been conducted to identify the relationship between dust/sand storms and RTAs [71-78]. Most of these studies have reported a positive and significant relationship between dust/sand storms and RTAs. For example, Shoemaker [73] found that sandstorm was the third ranked weather event in Arizona for RTAs and led to most of RTAs deaths and injuries from 1955 to 2004. Sandstorm-related accidents occur statewide, with a concentration on interstate highways, especially those with the greatest traffic density. Solomon [71] stated that dust/sand storms were powerful enough to cause extremely low visibility, resulting in severe road traffic accidents and damage to the economy. Conversely, other researches have illustrated that there is a negative relationship between weather and road traffic accident rate [79].

Based on the review of the impacts of temperature, rainfall, and dust/sand storms on RTAs across the world, the following research questions underpin this study:

1. Is there a positive relationship between climate change (such as rainfall, temperature, dust/sand storms) and RTAs?

2. Is the impact of climate change on RTAs higher inside cities than outside cities?

\section{Materials and Methods}

\subsection{Data}

To investigate the impact of climate change on road traffic accidents in Saudi Arabia, this study employed annual data from 13 regions from 2003 to 2013 and 143 observations. The data were retrieved from various sources such as World Bank, Ministry of Interior and Presidency of Meteorology and Environment of Saudi Arabia, Our World in Data, and Global Health Data Exchange [5,80-83].

\subsection{Variables and Model}

This article estimated how the climate change variables influenced road traffic accidents, considering empirical evidence from Saudi Arabia and using the following models:

$$
\begin{aligned}
& \mathrm{ICA}_{\mathrm{it}}=\alpha_{0}+\beta_{1} \mathrm{ATM}_{\mathrm{it}}+\beta_{2} \mathrm{ARF}_{\mathrm{it}}+\beta_{3} \mathrm{FST}_{\mathrm{it}}+\beta_{4} \mathrm{TVH}_{\mathrm{it}}+\varepsilon_{\mathrm{it}} \\
& \mathrm{OCA}_{\mathrm{it}}=\alpha_{0}+\beta_{1} \mathrm{ATM}_{\mathrm{it}}+\beta_{2} \mathrm{ARF}_{\mathrm{it}}+\beta_{3} \mathrm{FST}_{\mathrm{it}}+\beta_{4} \mathrm{TVH}_{\mathrm{it}}+\varepsilon_{\mathrm{it}} \\
& \mathrm{TAC}_{\mathrm{it}}=\alpha_{0}+\beta_{1} \mathrm{ATM}_{\mathrm{it}}+\beta_{2} \mathrm{ARF}_{\mathrm{it}}+\beta_{3} \mathrm{FST}_{\mathrm{it}}+\beta_{4} \mathrm{TVH}_{\mathrm{it}}+\varepsilon_{\mathrm{it}}
\end{aligned}
$$

where ICA = inside-city accidents, OCA = outside-city accidents, TAC = total number of accidents, $\mathrm{ATM}=$ average temperature, $\mathrm{ARF}=$ average rainfall, $\mathrm{FST}=$ frequency of sandstorms, $\mathrm{TVH}=$ total vehicles, $\mathrm{i}=$ region, $\mathrm{t}=$ time, $\varepsilon=$ error term, $\alpha=$ intercept, and $\beta=$ coefficient of the explanatory variables.

This article further estimated accidents leading to injury and death from different types of road traffic accidents, including empirical evidence from Saudi Arabia and using the following models:

$$
\mathrm{TIJ}_{\mathrm{it}}=\alpha_{0}+\beta_{1} \mathrm{ICA}_{\mathrm{it}}+\beta_{2} \mathrm{OCA}_{\mathrm{it}}+\varepsilon_{\mathrm{it}}
$$




$$
\begin{gathered}
\mathrm{TIJ}_{\mathrm{it}}=\alpha_{0}+\beta_{\mathrm{TAC}}+\varepsilon_{\mathrm{it}} \\
\mathrm{TOD}_{\mathrm{it}}=\alpha_{0}+\beta_{1} \mathrm{TIJ}_{\mathrm{it}}+\beta_{2} \mathrm{ICA}_{\mathrm{it}}+\beta_{3} \mathrm{OCA}_{\mathrm{it}}+\varepsilon_{\mathrm{it}} \\
\mathrm{TOD}_{\mathrm{it}}=\alpha_{0}+\beta_{1} \mathrm{TIJ}_{\mathrm{it}}+\beta_{2} \mathrm{TAC}_{\mathrm{it}}+\varepsilon_{\mathrm{it}} \\
\mathrm{PDD}_{\mathrm{it}}=\alpha_{0}+\beta_{1} \mathrm{TIJ}_{\mathrm{it}}+\beta_{2} \mathrm{ICA}_{\mathrm{it}}+\beta_{3} \mathrm{OCA}_{\mathrm{it}}+\varepsilon_{\mathrm{it}} \\
\mathrm{PDD}_{\mathrm{it}}=\alpha_{0}+\beta_{1} \mathrm{TIJ}_{\mathrm{it}}+\beta_{2} \mathrm{TAC}_{\mathrm{it}}++\varepsilon_{\mathrm{it}} \\
\mathrm{CYD}_{\mathrm{it}}=\alpha_{0}+\beta_{1} \mathrm{TIJ}_{\mathrm{it}}+\beta_{2} \mathrm{ICA}_{\mathrm{it}}+\beta_{3} \mathrm{OCA}_{\mathrm{it}}+\varepsilon_{\mathrm{it}} \\
\mathrm{CYD}_{\mathrm{it}}=\alpha_{0}+\beta_{1} \mathrm{TIJ}_{\mathrm{it}}+\beta_{2} \mathrm{TAC}_{\mathrm{it}}+\varepsilon_{\mathrm{it}} \\
\mathrm{MCD}_{\mathrm{it}}=\alpha_{0}+\beta_{1} \mathrm{TIJ}_{\mathrm{it}}+\beta_{2} \mathrm{ICA}_{\mathrm{it}}+\beta_{3} \mathrm{OCA}_{\mathrm{it}}+\varepsilon_{\mathrm{it}} \\
\mathrm{MCD}_{\mathrm{it}}=\alpha_{0}+\beta_{1} \mathrm{TIJ}_{\mathrm{it}}+\beta_{2} \mathrm{TAC}_{\mathrm{it}}+\varepsilon_{\mathrm{it}} \\
\mathrm{MVD}_{\mathrm{it}}=\alpha_{0}+\beta_{1} \mathrm{TIJ}_{\mathrm{it}}+\beta_{2} \mathrm{ICA}_{\mathrm{it}}+\beta_{3} \mathrm{OCA}_{\mathrm{it}}+\varepsilon_{\mathrm{it}} \\
\mathrm{MVD}_{\mathrm{it}}=\alpha_{0}+\beta_{1} \mathrm{TIJ}_{\mathrm{it}}+\beta_{2} \mathrm{TAC}_{\mathrm{it}}+\varepsilon_{\mathrm{it}}
\end{gathered}
$$

where TIJ $=$ total number of injuries, TOD $=$ total number of deaths, PDD = pedestrian death, $\mathrm{CYD}=$ cyclist death, $\mathrm{MCD}=$ motorcyclist death, $\mathrm{MVD}=$ motor vehicle death .

To draw an inference, the study employed three static regression models: fixed effect (FE), random effect (RE), and the pooled ordinary least square (POLS) models. These three panel models have their own individual assumptions in modelling the relationship between a dependent variable and its predictors. For example, the POLS assumptions include neglecting the individual heterogeneity by imposing a common intercept and slope coefficient for all cross sections in the estimation. The FE model assumes the individual effect of intercepts that correlate with the explanatory variables, while the RE model assumes no correlation between individual effect and the predictor variables of the model. Therefore, to find out the best model, this study relied on the Hausman test.

\section{Results}

\subsection{Descriptive Analysis}

The descriptive statistics of the variables showed that, on average, in Saudi Arabia, TAC was 30,619 , which is very alarming (Table 1). It was also seen that inside cities, the number of accidents was more than four times higher than outside cities. Moreover, on average, the number of injuries (2832) was four times higher than the number of deaths (696) at the time of occurrence of the accidents. Additionally, the highest number of deaths concerned motor vehicle drivers and passengers, followed by pedestrians, motorcyclists, and cyclists. As shown in Table 1, pedestrians were also highly affected by road accidents in Saudi Arabia. Besides, road accidents also included frequent crashes among motor vehicles, motor cyclists, and pedestrians.

On the other hand, the climatic variables, including temperature, rainfall and sandstorms, were also very hazardous in the city. During the study period, the average number of sandstorms in Saudi Arabia was 3.48 with a maximum of 14 events in a year. Similarly, heat was also very severe, since the average temperature during the study time was around $26^{\circ} \mathrm{C}$. The average rainfall was $4 \mathrm{in}$. in a year, which is very small compared to the other parts of the world. Though the average rainfall was very low, it was responsible for many RTAs in cities. The potential reasons could be the low quality of road construction, irregular road maintenance, irregular inspections of the drainage points and equipment, urban expansion, and heavy rain falls in short periods of time. 
Table 1. Descriptive statistics of the variables ${ }^{\text {a }}$.

\begin{tabular}{|c|c|c|c|c|c|c|}
\hline & Variable Name & Observation & Mean & $\begin{array}{l}\text { Standard } \\
\text { Deviation }\end{array}$ & $\begin{array}{l}\text { Minimum } \\
\text { Value }\end{array}$ & $\begin{array}{l}\text { Maximum } \\
\text { Value }\end{array}$ \\
\hline TOD & Total number of deaths & 143 & 695.7 & 29.02 & 649 & 739 \\
\hline PDD & Pedestrian death & 143 & 134.55 & 6.55 & 130 & 154 \\
\hline CYD & Cyclist death & 143 & 10.10 & 0.67 & 9 & 12 \\
\hline MCD & Motorcyclist death & 143 & 29.40 & 1.62 & 26 & 31 \\
\hline MVD & $\begin{array}{l}\text { Motor vehicle (drivers and } \\
\text { passengers) death }\end{array}$ & 143 & 521 & 29.37 & 462 & 556 \\
\hline TIJ & Total injuries & 143 & 2832.30 & 3237.85 & 88 & 14,932 \\
\hline ICA & Inside-city accidents & 143 & $25,413.44$ & $37,220.81$ & 461 & 165,853 \\
\hline OCA & Outside-city accidents & 143 & 5205.46 & 6372.81 & 27 & 31,907 \\
\hline TAC & Total number of accidents & 143 & 30,619 & $40,755.12$ & 1103 & 166,814 \\
\hline ATM & Avg temperature & 143 & 26 & 2.96 & 20 & 33 \\
\hline ARF & Avg rainfall & 143 & 4.00 & 1.76 & 0.5 & 9.33 \\
\hline FST & Frequency of sandstorm & 143 & 3.48 & 3.62 & 0 & 14 \\
\hline TVH & Total number of vehicles & 143 & $382,391.5$ & $77,408.50$ & 275,385 & 507,692 \\
\hline
\end{tabular}

Source: ${ }^{a}$ World Bank, Ministry of Interior and Presidency of Meteorology and Environment of Saudi Arabia, Our World in Data, and Global Health Data Exchange.

\subsection{Regression Analysis}

Based on the Hausman test [84], only the best-fit models (POLS, RE, or FE) are reported in the following tables and analyses. Table 2 displays the outcome of the models which investigated the impact of climate change on road traffic accidents in Saudi Arabia. The findings of model 1 revealed that the ATM, ARF, FST, and TVH caused statistically significant increases in the rate of ICA. Similarly, the regression model 2 revealed that the ATM and ARF caused a significant rise in the rate of OCA; on the other hand, the TVH and FST were not significant for the rate of OCA. Moreover, the outcome of model 3 indicated that ATM, ARF, FST, and TVH had positive and statistically significant impacts on the total number of accidents.

Table 2. Regression analysis for the prediction of inside-city accidents, outside-city accidents, and total accidents in relation to average temperature, average rainfall, frequency of sandstorms, and total vehicles.

\begin{tabular}{cccc}
\hline Variables & $\begin{array}{c}\text { Model 1: (POLS) } \\
\text { DV=ICA }\end{array}$ & $\begin{array}{c}\text { Model 2: (POLS) } \\
\text { DV=OCA }\end{array}$ & $\begin{array}{c}\text { Model 3: (POLS) } \\
\text { DV=TAC }\end{array}$ \\
\hline \multirow{2}{*}{ ATM } & $4691.04^{* * *}$ & $688.86^{* * *}$ & $5379.91^{* * *}$ \\
& $(-931.59)$ & $(-163.32)$ & $(-1000.09)$ \\
ARF & $6960.86^{* * *}$ & $1343.43^{* * *}$ & $8304.3^{* * *}$ \\
& $(-1567.65)$ & $(-274.83)$ & $(-1682.91)$ \\
FST & $1610.9^{* *}$ & 22.69 & $1633.6^{* * *}$ \\
& $(-759.14)$ & $(-133.09)$ & $(-814.95)$ \\
TVH & $0.086^{* * *}$ & -0.012 & $0.099^{* *}$ \\
Constant & $(-0.035)$ & $(-0.006)$ & $(-0.038)$ \\
\hline
\end{tabular}

Note: The values in parentheses represent the error; the symbols ${ }^{* *},{ }^{* * *}$ stand for significant probability value at $p<0.05$ and $<0.01$, respectively.

In addition, Table 3 displays the output of the models and shows that road traffic accidents caused injuries and deaths in Saudi Arabia. Models 4 and 5 indicated that ICA, OCA, and TAC caused statistically significant increases in the total number of injuries. As shown in model 6, the TIJ had a positive and statistically significant impact on the TOD. In the same model, it is observed that the inside city accidents (ICA) also had a positive and statistically significant impact on the TOD, but the OCA had no impact on the TOD. As shown in model 7, both the TIJ and the TAC had significant and positive impacts on related deaths. 
Table 3. Regression analysis for the prediction of total injuries, total number of deaths by total injuries, inside-city accidents, outside-city accidents, and total number of accidents

\begin{tabular}{ccccc}
\hline Variables & $\begin{array}{c}\text { Model 4: (RE) } \\
\text { DV=TIJ }\end{array}$ & $\begin{array}{c}\text { Model 5: (FE) } \\
\text { DV=TIJ }\end{array}$ & $\begin{array}{c}\text { Model 6: (FE) } \\
\text { DV=TOD }\end{array}$ & $\begin{array}{c}\text { Model 7: (FE) } \\
\text { DV=TOD }\end{array}$ \\
\hline TIJ & & $0.004^{* *}$ & $0.004^{* *}$ \\
& & $(-0.002)$ & $(-0.001)$ \\
ICA & $0.011^{* *}$ & & $0.0006^{* * *}$ & \\
OCA & $(-0.005)$ & & $(-0.0001)$ & \\
TAC & $0.124^{* * *}$ & & 0.001 & \\
Constant & $(-0.028)$ & & $(-0.0007)$ & $0.0006^{* * *}$ \\
& & $0.017^{* *}$ & & $(-0.00001)$ \\
\hline
\end{tabular}

Note: The values in parentheses represent the error; the symbols ${ }^{* *},{ }^{* *}$ stand for significant probability value at $p<0.05$ and $<0.01$, respectively.

Furthermore, Table 4 shows different types of road traffic accidents that led to deaths in Saudi Arabia. The regression models 8 and 9 revealed that TIJ, ICA, and OCA had no statistically significant impact on PDD. Moreover, the models 10 and 11 revealed that both TIJ and OCA had no significant impact on CYD, but ICA and TAC contributed significantly to the increase in the CYD.

Table 4. Regression analysis for the prediction of pedestrian death, cyclist death, motorcyclists death, and motor vehicle death by total injuries, inside-city accidents, outside-city accidents, and total number of accidents.

\begin{tabular}{|c|c|c|c|c|c|c|c|c|}
\hline Variables & $\begin{array}{l}\text { Model 8: } \\
\text { (POLS) } \\
\text { DV=PDD }\end{array}$ & $\begin{array}{l}\text { Model 9: } \\
\text { (POLS) } \\
\text { DV=PDD }\end{array}$ & $\begin{array}{l}\text { Model 10: } \\
\quad(F E) \\
\text { DV=CYD }\end{array}$ & $\begin{array}{l}\text { Model 11: } \\
\quad \text { (FE) } \\
\text { DV=CYD }\end{array}$ & $\begin{array}{c}\text { Model } \\
\text { 12:(FE) } \\
\text { DV=MCD }\end{array}$ & $\begin{array}{l}\text { Model 13: } \\
\text { (FE) } \\
\text { DV=MCD }\end{array}$ & $\begin{array}{c}\text { Model 14: } \\
\text { (FE) } \\
\text { DV=MVD }\end{array}$ & $\begin{array}{l}\text { Model 15: } \\
\text { (FE) } \\
\text { DV=MVD }\end{array}$ \\
\hline TIJ & $\begin{array}{c}-0.00005 \\
(0.0002)\end{array}$ & $\begin{array}{c}-0.00004 \\
(0.0002)\end{array}$ & $\begin{array}{c}6.751 \\
(0.0005)\end{array}$ & $\begin{array}{c}0.00002 \\
(0.00004)\end{array}$ & $\begin{array}{c}0.0001 \\
(0.0001)\end{array}$ & $\begin{array}{c}0.0001 \\
(0.00009)\end{array}$ & $\begin{array}{l}0.004^{* *} \\
(0.002)\end{array}$ & $\begin{array}{l}0.004^{* *} \\
(0.001)\end{array}$ \\
\hline ICA & $\begin{array}{c}-9.070 \\
(0.0001)\end{array}$ & & $\begin{array}{l}6.771^{*} \\
(3.460)\end{array}$ & & $\begin{array}{c}0.0003^{* * *} \\
(6.89)\end{array}$ & & $\begin{array}{c}0.0006^{* * *} \\
(0.0001)\end{array}$ & \\
\hline OCA & $\begin{array}{c}7.560 \\
(0.0001)\end{array}$ & & $\begin{array}{c}0.00002 \\
(0.00001)\end{array}$ & & $\begin{array}{c}0.00002 \\
(0.00003)\end{array}$ & & $\begin{array}{c}0.001 \\
(0.0007)\end{array}$ & \\
\hline TAC & & $\begin{array}{c}-7.890 \\
(0.00001)\end{array}$ & & $\begin{array}{l}7.92 * * \\
(3.25)\end{array}$ & & $\begin{array}{c}0.00003^{* * *} \\
(0.0001)\end{array}$ & & $\begin{array}{c}0.0006^{* * *} \\
(0.0001)\end{array}$ \\
\hline Constant & 134.79 & 134.81 & 9.846 & 9.864 & 28.14 & 28.13 & 486.17 & 486.52 \\
\hline
\end{tabular}

Note: The values in parentheses represent the error; the symbols ${ }^{*}, * * * * *$ stand for significant probability value at $p<0.10,<0.05$, and $<0.01$, respectively.

Similarly, models 12 and 13 revealed that both ICA and TAC statistically and significantly increased the rate of MCD, but both TIJ and OCA did not have any significant impact on MCD. However, the models 14 and 15 found that except for OCA, TIJ, ICA, and TAC contributed statistically and significantly to increases in the rate of MVD.

\section{Discussion}

The purpose of this study was to assess, with an extensive statistical analysis, the impact of climate change on RTAs in Saudi Arabia due to changes in temperature, rainfall, and sandstorms. The study found that temperature, rainfall, sandstorms, and number of vehicles were responsible for the increase in the rate of road accidents.

The findings of this study revealed that an increase in the average temperature caused a statistically significant increase in the rate of RTAs, and ICAs were more frequent than OCAs. This result is supported by studies conducted by Yannis and Karlaftis [67], Basagana et al. [63], Al-Harbi et al. [66], Wåhlberg [68], Brijs et al. [69], Stipdonk [70], Hermans et al. [57]. A potential explanation for this result is related to the physiological or psychological effects of high temperatures on drivers, such as altered 
emotions, increased irritability, reaction time, and fatigue, and decreased concentration, all of which would have detrimental effects on drivers' performance. Additionally, an increase in traffic volume during shiny hot days could be another potential reason for road accidents.

This study also has found a positive and significant relationship between the FSTs and the rate of road accidents. Therefore, this study supports the findings of the majority of previous studies [71-78,85,86]. For example, Al-Hemoud et al. [85] stated that sandstorm was a significant contributory factor to RTAs in Gulf Areas. Moreover, Maghrabi et al. [87] conducted a study on the impact of dust on road accidents in Saudi Arabia in March 2009 and found extensive damage to vehicles and a high number of RTAs. The possible reason for this result could be the poor visibility and traffic congestion produced by sand/dust storms. In addition, the lack of public alerts issued by relevant departments could be another potential reason for road accidents.

The results of this study also showed a positive and significant impact of rainfall on RTAs in Saudi Arabia. This finding is supported by many previous studies [45,52-59] reporting that RTAs increase during rainfall. For example, Bergel-Hayat et al. [54] reported that the risk of crash during rain was greater than in dry weather. Another study by Qayed [88] conducted in the city of Al-Ahsaa confirmed that in December, $13.7 \%$ of RTAs happened, and this percentage was considerably higher than in those of other months due to the higher frequency of rainfalls. In contrast, the lowest number of RTAs occurred in February, with a rate of $5.8 \%$. As rainfall leads to wet, slick, and slippery roads, reduces visibility, increases humidity that clouds windows and windscreens, reduces the friction of the road surface, blinds drivers at night due to the reflection of the headlights of oncoming vehicles on the waterlogged roads during heavy rainfalls, it makes roads dangerous for motorists. These, all together, are the potential reason for the higher rate of RTAs.

Furthermore, both inside- and outside-city accidents significantly caused injuries, but only inside-city accident showed a positive and statistically significant impact on road traffic accident-related deaths. The majority of previous studies also support our findings by stating that the injury-related fatalities were deaths caused by road traffic accidents [89]. In addition, both inside- and outside-city accident were not statistically and significantly related to the death of the pedestrians, and only inside-city accident statistically and significantly caused cyclist, motorcyclist, and motor vehicle deaths. Furthermore, only in the case of motor vehicle accidents, the injuries caused by the accident later led to deaths. This finding related to cyclists is supported by many studies [90-93]. Moreover, most of the cyclist accidents occurred in urban areas because the cyclists collided with trucks and cars. The deaths caused by collisions were only motor vehicle deaths [94,95]. Similarly, the findings regarding motor vehicle deaths are also supported by other studies, like those of Cheng et al. [96], Jama et al. [97], and Lucidi et al. [98]. There are many measures that have been already taken to reduce RTAs in Saudi Arabia. For example, seat belt fastening is compulsory for the front seaters, and there will be a fine if the seat belt is not fastened. Moreover, speed cameras have been installed extensively in main cities, such as Jeddah and Riyadh, and the cities are controlled by the Saudi Traffic Police (STP). In addition, the STP can record road collisions and mortalities [13]. As a result, the reporting system of injuries and accidents has been substantially improved in recent years. Overall, there is still room for improvement in Saudi traffic road systems.

\section{Conclusions}

In Saudi Arabia, RTAs strongly contribute to health problems that influence the Saudi economy negatively and significantly. Based on our results, it is suggested that focusing on road traffic injuries is highly important to determine the reasons behind road accidents. Though road accidents can be investigated from many perspectives, the impact and importance of external factors, like climatic issues, on road accidents have received little attention. Climate change is causing a sharp increase in temperature and rate of sandstorms and is altering rainfall patterns in Saudi Arabia as in other parts of the world. To address such issue, this study has attempted to investigate the impacts of sandstorms, temperature, and rainfall on road traffic accidents in Saudi Arabia. 
Considering climate issues, this study has found that temperature, rainfall, sandstorms, and number of vehicles were responsible for increasing RTAs in Saudi Arabia. It can be observed that climate change certainly poses risk to road safety in Saudi Arabia by increasing the number of road traffic accidents. However, due to a relatively small sample size and limited amount of available data, the findings of this study cannot be generalized to other Middle East and developing countries. This study also found that different types of RTAs led to injuries and deaths in Saudi Arabia.

To conclude, the negative impacts of climate change on road accidents can be mitigated through possible adaptation measures, as climate change is a slow phenomenon. This can be done through warning signs, roads improvements, and safety campaigns. Therefore, the impacts of increased temperature, altered rainfall patterns, and higher rate of sandstorms in Saudi Arabia can easily be reduced by increaed preparedness, traffic safety culture, and awareness at local and community levels of the impacts of climate change on road safety and of human vulnerability. The relevant authorities and driving training schools can play a major role in this regard. In addition, the use of modern information dissemination technologies, tools, and media might help to increase public awareness. The road infrastructure also needs to be designed in a manner that reduces waterlogging, considering that the return period of major extreme events is likely to decrease considerably. Moreover, the government of Saudi Arabia must do more for cyclists by assigning them paths and lanes. This means that the cycling infrastructure could be improved in both cities and rural areas. Moreover, in shared road environments, it is important to increase awareness among pedestrians, cyclists, and motorists, with appropriate programs. These courses of action to mitigate the negative impacts of climate will help not only to reduce RTAs, related injuries, deaths, and property damage but also to achieve sustainability in road transport.

Finally, the findings of this study will help policymakers to make effective traffic polices related to extreme-weather climatic issues in Saudi Arabia and other similar countries. Moreover, further research will help to overcome the limitations and to validate the findings of the study. We expect future research will explore the impact of climate change on RTAs using different sets of rainfall data, such as rainfall only on road areas or only heavy-frequency rainfall events, as well as data with more control variables, such as demographic, cultural, and socioeconomic features.

Author Contributions: M.M.I. had the original idea to explore the impact of climate change on RTAs in Saudi Arabia. M.M.I. and M.M.A. participated in the conception of the study, design of the analysis, writing of the results, and drafting of the manuscript. M.A. collected data and edited the English.

Acknowledgments: The project was funded by the Deanship of Scientific Research (DSR), King Abdulaziz University, Jeddah, under grant no. (G: 173-849-1439). The authors, therefore, acknowledge with thanks DSR technical and financial support.

Conflicts of Interest: The authors declare no conflicts of interest.

\section{References}

1. AASHTO. Highway Safety Manual; American Association of State Highway and Transportation Officials: Washington, DC, USA, 2010.

2. WHO. Global Status Report on Road Safety 2015; World Health Organization: Geneva, Switzerland, 2015.

3. WHO. Global Status Report on Road Safety 2018; World Health Organization: Geneva, Switzerland, 2018.

4. Jacobs, G.; Aeron-Thomas, A.; Astrop, A. Estimating Global Road Fatalities; TRL Report No. 445; Transport Research Laboratory: Crowthorne, UK, 2000.

5. World Bank. Climate Change Knowledge Portal: For Development Practitioners and Policy Makers. 2016. Available online: http://sdwebx.worldbank.org/climateportal/index.cfm?page=downscaled_data_ download\&menu=historical (accessed on 10 May 2018).

6. Association for Safe International Road Travel (ASIRT). Annual Global Road Crash Statistics. 2013. Available online: https://www.asirt.org/safe-travel/road-safety-facts/ (accessed on 21 August 2019).

7. WHO. Global Status Report on Road Safety 2013; World Health Organization: Geneva, Switzerland, 2013. 
8. Broughton, J.; Johnson, B.; Knight, I.; Lawton, B.; Lynam, D.; Whitfield, P.; Allsop, R. Road Safety Strategy Beyond 2010-A Scoping Study; Road Safety Research Report No. 105; Department for Transport: London, UK, 2009.

9. Wegman, F.; Hagenzieker, M. Editorial safety science special issue road safety management. SWOV Inst. Road Saf. Res. 2010, 48, 1081-1084. [CrossRef]

10. Hijar, M.; Carrillo, C.; Flores, M.; Anaya, R.; Lopez, V. Risk factors in highway traffic accidents: A case control study. Accid. Anal. Prev. 2000, 32, 703-709. [CrossRef]

11. Mannering, F.L.; Shankar, V.; Bhat, C.R. Unobserved heterogeneity and the statistical analysis of highway accident data. Anal. Methods Accid. Res. 2016, 11, 1-16. [CrossRef]

12. Barrimah, I.; Midhet, F.; Sharaf, F. Epidemiology of road traffic injuries in qassim region, saudi arabia: Consistency of police and health data. Int. J. Health Sci. 2012, 6, 31-41. [CrossRef]

13. Mansuri, F.A.; Al-Zalabani, A.H.; Zalat, M.M.; Qabshawi, R.I. Road safety and road traffic accidents in Saudi Arabia: A systematic review of existing evidence. Saudi Med. J. 2015, 36, 418-424. [CrossRef]

14. Wintemute, G.J. Is motor vehicle-related mortality a disease of development. Accid. Anal. Prev. 1985, 17, 223-237. [CrossRef]

15. Aarts, L.; Van Schagen, I. Driving speed and the risk of road crashes: A review. Accid. Anal. Prev. 2006, 38, 215-224. [CrossRef] [PubMed]

16. Soderlund, N.; Zwi, A.B. Traffic-related mortality in industrialized and less developed countries. Bull. World Health Organ. 1995, 73, 175-182. [PubMed]

17. Van Beeck, E.F.; Borsboom, G.J.; Mackenbach, J.P. Economic development and traffic accident mortality in the industrialized world, 1962-1990. Int. J. Epidemiol. 2000, 29, 503-509.

18. Lee, W.K.; Lee, H.A.; Hwang, S.S.; Kim, H.; Lim, Y.H.; Hong, Y.C. A time series study on the effects of cold temperature on road traffic injuries in Seoul, Korea. Environ Res. 2014, 132, 290-296. [CrossRef]

19. WHO. Global Tuberculosis Control, WHO Report 2011; World Health Organization: Geneva, Switzerland, 2011.

20. Alvarez, F.J.; Fierro, I. Older drivers, medical condition, medical impairment and crash risk. Accid. Anal. Prev. 2008, 40, 55-60. [CrossRef] [PubMed]

21. Vision 2030 Kingdom of Saudi Arabia. 2016. Available online: https://www.vision2030.gov.sa (accessed on 12 May 2019).

22. Qiu, L.; Nixon, W.A. Effects of adverse weather on traffic crashes: Systematic review and meta-analysis. Transp. Res. Rec. 2008, 2055, 139-146. [CrossRef]

23. Andrey, J. Long-term trends in weather-related crash risks. J. Transp. Geogr. 2010, 18, 247-258. [CrossRef]

24. Bener, A.; Al Maadid, M.G.; Ozkan, T.; Al-Bast, D.A.; Diyab, K.N.; Lajunen, T. The impact of four-wheel drive on risky driver behaviours and road traffic accidents. Transp. Res. Part F Traffic Psychol. Behav. 2008, 11, 324-333. [CrossRef]

25. Hassan, H.M. Investigation of the self-reported aberrant driving behavior of young male Saudi drivers: A survey-based study. J. Transp. Saf. Secur. 2015, 8, 113-128. [CrossRef]

26. Ministry of Interior. The Statistical Report for the Year of 1431H; General Administration of Traffic: Riyadh, Saudi Arabia, 2010.

27. Al-Turki, Y.A. How can Saudi Arabia use the Decade of Action for Road Safety to catalyse road traffic injury prevention policy and interventions? Int. J. Inj. Control Saf. Promot. 2014, 21, 397-402. [CrossRef] [PubMed]

28. Ansari, S.; Akhdar, F.; Mandoorah, M.; Moutaery, K. Causes and effects of road traffic accidents in Saudi Arabia. Public Health 2000, 114, 37-39. [CrossRef]

29. Saudi Arabia Monetary Agency. The 32nd Annual Report 1417H; The Economical and Statistical Research Office: Riyadh, Saudi Arabia, 1997.

30. Al-Atawi, A.; Saleh, W. Travel behaviour in Saudi Arabia and the role of social factors. Transport 2014, 29, 269-277. [CrossRef]

31. Transport Ministry. Annual Report 2018; Ministry of Transport, Kingdom of Saudi Arabia. 2018. Available online: https://www.mot.gov.sa/ar/AboutUs/Documents/MOT\%20annual\%20report\%202018\%20vertical\% 20A\%20V7\%20LO_-.pdf (accessed on 10 January 2019).

32. WHO. Deaths on the Roads: Based on the WHO Global Status Report on Road Safety 2015; World Health Organisation: Geneva, Switzerland, 2015.

33. Arab News. The Signs of Climate Change in the Middle East. 3 April 2019. Available online: http: //www.arabnews.com/node/1477366 (accessed on 10 January 2019). 
34. Tarawneh, Y.Q.; Chowdhury, S. Trends of Climate Change in Saudi Arabia: Implications on Water Resources. Climate 2018, 6, 8. [CrossRef]

35. Almazroui, M.; Nazrul Islam, M.; Athar, H.; Jonesa, P.D.; Ashfaqur Rahmana, M. Recent climate change in the Arabian Peninsula: Annual rainfall and temperature analysis of Saudi Arabia for 1978-2009. Int. J. Climatol. 2012, 32, 953-966. [CrossRef]

36. Chowdhury, S.; Al-Zahrani, M. Implications of Climate Change on Water Resources in Saudi Arabia. Arab. J. Sci. Eng. 2013, 38, 1959-1971. [CrossRef]

37. Albugami, S.; Palmer, S.; Cinnamon, J.; Meersmans, J. Spatial and Temporal Variations in the Incidence of Dust Storms in Saudi Arabia Revealed from In Situ Observations. Geosciences 2019, 9, 162. [CrossRef]

38. Herslund, M.B.; Jørgensen, N.O. Looked-but-failed-to-see-errors in traffic. Accid. Anal. Prev. 2003, 35, 885-891. [CrossRef]

39. Groeger, J.A. Frontiers of Cognitive Science. Understanding Driving: Applying Cognitive Psychology to a Complex Everyday Task; Psychology Press: New York, NY, USA, 2000.

40. Shahid, S.; Minhans, A. Climate change and road safety: A review to assess impacts in Malaysia. J. Teknol. 2016, 78, 1-8. [CrossRef]

41. Cromley, E.K. Risk factors contributing to motor vehicle accidents in an environment of uncertainty. Stoch. Environ. Res. Risk Assess. 2007, 21, 363-376. [CrossRef]

42. Palutikof, J.P. Road Accidents and Weather. In Highway Meteorology; Perry, A.H., Symons, L.J., Eds.; E. \& F.N. Spon: London, UK, 1991; pp. 163-189.

43. Edwards, J.B. Weather-related road accidents in England and Wales: A spatial analysis. J. Transp. Geogr. 1996, 4, 201-212. [CrossRef]

44. Edwards, J.B. The temporal distribution of road accidents in adverse weather. Meteorol. Appl. 1999, 6, 59-68. [CrossRef]

45. Perrels, A.; Votsis, A.; Nurmi, V.; Pilli-Sihvola, K. Weather Conditions, Weather Information and Car Crashes. ISPRS Int. J. Geo-Inf. 2015, 4, 2681-2703. [CrossRef]

46. Andrey, J.C.; Mills, B.; Leahy, M.; Suggett, J. Weather as a chronic hazard for road transportation in Canadian cities. Nat. Hazards 2003, 28, 319-343. [CrossRef]

47. Eisenberg, D.; Warner, K. Effects of snowfalls on motor vehicle Collisions, Injuries, and Fatalities. Am. J. Public Health 2005, 95, 120-124. [CrossRef]

48. Fridstrom, L. Econometric Models of Road Use, Accidents, and Road Investment Decisions; Institute of Transport Economics: Oslo, Norway, 1999.

49. Musk, L. Climate as a Factor in the Planning and Design of New Roads and Motorways. In Highway Meteorology; Perry, A.H., Symons, L.J., Eds.; E. \& F.N. Spon: London, UK, 1991; pp. 1-25.

50. White, M.E.; Jeffrey, D.J. Some Aspects of Motorway Traffic Behaviour in Fog; TRL: Crowthorne, UK, 1980.

51. Musk, L.F. The local fog hazard as a factor in planning new roads and motorways. Env. Educ. Plan. 1982, 2, 119-129.

52. Jaroszweski, D.; McNamara, T. The influence of rainfall on road accidents in urban areas: A weather radar approach. Travel Behav. Soc. 2014, 1, 15-21. [CrossRef]

53. Jaroszweski, D.; Chapman, L.; Petts, J. Climate Change and Road Freight Safety: A Multidisciplinary Exploration. Clim. Chang. 2013, 120, 785-799. [CrossRef]

54. Bergel-Hayat, R.; Debbarh, M.; Antoniou, C.; Yannis, G. Explaining the road accident risk: Weather effects. Accid. Anal. Prev. 2013, 60, 456-465. [CrossRef] [PubMed]

55. Hambly, D.; Andrey, J.; Mills, B.; Fletcher, C. Projected implications of climate change for road safety in Greater Vancouver, Canada. Clim. Chang. 2013, 116, 613-629. [CrossRef]

56. Martí, I.; Tomás, V.R.; García, L.A.; Martínez, J.J. A Multi-Agent System for Managing Adverse Weather Situations on the Road Network. Integr. Comput. Aided Eng. 2010, 17, 145-155. [CrossRef]

57. Hermans, E.; Wets, G.; Van Den Bossche, F. Frequency and severity of Belgian road traffic accidents studied by state-space methods. J. Transp. Stat. 2006, 9, 63-76.

58. Eisenberg, D. The mixed effects of precipitation on traffic crashes. Accid. Anal. Prev. 2004, 36, 637-647. [CrossRef]

59. Fridstrom, L.; Ifver, J.; Ingebrigtsen, S.; Kulmala, R.; Thomsen, L.K. Measuring the contribution of randomness, exposure, weather, and daylight to the variation in road accident counts. Accid. Anal. Prev. 1995, 27, 1-20. [CrossRef] 
60. Mondal, P.; Sharma, N.; Kumar, A.; Bhangale, U.D.; Tyagi, D.; Singh, R. Effect of Rainfall and Wet Road Condition on Road Crashes: A Critical Analysis. SAE Tech. 2011. [CrossRef]

61. Keay, K.; Simmonds, I. The Association of Rainfall and other Weather Variables with Road Traffic Volume in Melbourne, Australia. Accid. Anal. Prev. 2005, 37, 109-124. [CrossRef] [PubMed]

62. Daanen, H.M.; Van De Vliert, E.; Huang, X. Driving performance in cold, warm, and thermoneutral environments. Appl. Erg. 2003, 34, 597-602. [CrossRef]

63. Basagana, X.; Escalera-Antezana, J.P.; Dadvand, P.; Llatje, O.; Barrera-Gomez, J.; Cunillera, J.; Medina-Ramón, M.; Perez, K. High ambient temperatures and risk of motor vehicle crashes in catalonia, spain (2000-2011): A time-series analysis. Env. Health Perspect. 2015, 123, 1309-1316. [CrossRef] [PubMed]

64. Liu, A.; Soneja, S.I.; Jiang, C.; Huang, C.; Kerns, T.; Beck, K.; Mitchell, C.; Sapkota, A. Frequency of extreme weather events and increased risk of motor vehicle collision in maryland. Sci. Total Env. 2017, 580, 550-555. [CrossRef] [PubMed]

65. Yaacob, H.; Hainin, M.R.; Nair, S.; Baskara, L. Effect of Rainfall Intensity and Road Crossfall on Skid Resistance of Asphalt Pavement. J. Teknol. 2014, 70, 121-125. [CrossRef]

66. Al-Harbi, M.; Yassin, M.F.; Shams, M.B. Stochastic Modeling of the Impact of Meteorological Conditions on Road Traffic Accidents. Stoch. Environ. Res. Risk Assess. 2012, 26, 739-750. [CrossRef]

67. Yannis, G.; Karlaftis, G.M. Weather Effects on Daily Traffic Accidents and Fatalities: A Time Series Count Data Approach. 2016. Available online: https://www.researchgate.net/publication/268416925_Weather_ Effects_on_Daily_Traffic_Accidents_and_Fatalities_A_Time_Series_Count_Data_Approach (accessed on 10 January 2019).

68. Wåhlberg, A.E. If You Can't Take The Heat: Influences of Temperature on Bus Accident Rates. Saf. Sci. 2008, 46, 66-71. [CrossRef]

69. Brijs, T.; Karlis, D.; Wets, G. Studying the effect of weather conditions on daily crash counts using a discrete time series model. Accid. Anal. Prev. 2008, 40, 1180-1190. [CrossRef]

70. Stipdonk, H.L. (Ed.) Time Series Applications on Road Safety Developments in Europe. Deliverable D7.10 of the EU FP6 Project SafetyNet. 2008. Available online: http://www.erso.eu/safetynet/fixed/WP7/SN_D7.10_ final.pdf (accessed on 10 January 2019).

71. Solomon, E. Real-Time Dust Storm Forecasting. Masdar News. 18 July 2016. Available online: https://news.masdar.ac.ae/explore-news/stories-by-type/transformation/item/9277-real-time-duststormforecasting.html (accessed on 6 January 2016).

72. Foreman, T. The Effects of Dust Storms on Economic Development. 2018. Available online: http://ic-sd.org/ wp-content/uploads/sites/4/2018/10/Timothy-Foreman.pdf (accessed on 11 January 2019).

73. Shoemaker, C.; Davis, J.T. Hazardous Weather Climatology for Arizona. NOAA Technical Memorandum, NWS-WR 282. 2008; p. 47. Available online: http://www.wrh.noaa.gov/wrh/techMemos/TM-282.pdf (accessed on 11 January 2019).

74. Morales, C. Saharan Dust: Mobilization, Transport, Deposition (SCOPE Report 14); John Wiley \& Sons: New York, NY, USA, 1979; pp. 233-242.

75. Hagen, L.J.; Woodruff, N.P. Air pollution from dust storms in the Great Plains. Atmos. Environ. 1973, 7, 323-332. [CrossRef]

76. Middleton, N.J.; Chaudhary, Q.Z. Severe dust storm at Karachi, 31 May 1986. Weather 1988, 438, $298-301$. [CrossRef]

77. Dayan, U.; Heffter, J.; Miller, J.; Gutman, G. Dust intrusion events into the Mediterranean Basin. J. Appl. Meteorol. 1991, 30, 1185-1199. [CrossRef]

78. Chung, Y.S.; Yoon, M.B. On the occurrence of yellow sand and atmospheric loadings. Atmos. Environ. 1996, 3013, 2387-2397. [CrossRef]

79. Staines, T. Car Crashes and the Weather: An Exploratory Analysis of Environmental Conditions' Impact on Traffic Accident Rates. 2018. Available online: https://towardsdatascience.com/car-crashes-and-theweather-an-exploratory-analysis-of-environmental-conditions-impact-on-traffic-12bcb7f9afed (accessed on 6 January 2019).

80. Ministry of Interior. Dataset Info. General Directorate of Traffic, Kingdom of Saudi Arabia. 2015. Available online: http://www.data.gov.sa/en/dataset/traffic-accidents (accessed on 10 May 2018). 
81. Presidency of Meteorology and Environment. Climate Report; General Authority for Meteorology and Environmental Protection, KSA. 2017. Available online: https://www.pme.gov.sa/Ar/Meteorology/Pages/ ClimateReport.aspx (accessed on 10 May 2018).

82. Our World in Data. Causes of Death: Road Incidents. 2018. Available online: https://ourworldindata.org/ causes-of-death\#road-incidents (accessed on 10 May 2018).

83. Global Health Data Exchange. Health Statistical Year Book. Ministry of Health, Saudi Arabia. 2017. Available online: http://ghdx.healthdata.org/geography/saudi-arabia (accessed on 12 May 2018).

84. Greene, W.H. Econometric Analysis; Pearson Education: Delhi, India, 2003.

85. Al-Hemoud, A.; Al-Dousari, A.; Misak, R.; Al-Sudairawi, M.; Naseeb, A.; Al-Dashti, H.; Al-Dousari, N. Economic Impact and Risk Assessment of Sand and Dust Storms (SDS) on the Oil and Gas Industry in Kuwait. Sustainability 2019, 11, 200. [CrossRef]

86. Al Harbi, B.H.; Moied, K. Riyadh Air Quality Report (1999-2004); Report No. 279-25-ER; King Abdulaziz City for Science and Technology: Riyadh, Saudi Arabia, 2005.

87. Maghrabi, A.; Alharbi, B.; Tapper, N. Impact of the March 2009 dust event in Saudi Arabia on aerosol optical properties, meteorological parameters, sky temperature and emissivity. Atmos. Environ. 2011, 45, 2164-2173. [CrossRef]

88. Qayed, M.H. Epidemiology of road traffic accidents in Al Ahsaa Governorate, Saudi Arabia. East Mediterr. Health J. 1998, 4, 513-520.

89. DeNicola, E.; Aburizaize, O.S.; Siddique, A.; Khwaja, H.; Carpenter, D.O. Road Traffic Injury as a Major Public Health Issue in the Kingdom of Saudi Arabia: A Review. Front. Public Health 2016, 4, 1-12. [CrossRef] [PubMed]

90. Allen-Munley, C.; Daniel, J. Urban Bicycle Route Safety Rating Model Application in Jersey City, New Jersey. J. Transp. Eng. 2006, 6, 499-507. [CrossRef]

91. Morgan, A.S.; Dale, H.B.; Lee, W.E.; Edwards, P.J. Deaths of cyclists in London: Trends from 1992 to 2006. BMC Public Health 2010, 10, 699. [CrossRef]

92. Manson, J.; Cooper, S.; West, A.; Foster, E.; Cole, E.; Tai, N.R.M. Major trauma and urban cyclists: Physiological status and injury profile. Emerg. Med. J. 2013, 30, 32-37. [CrossRef]

93. Pokorny, P.; Drescher, J.; Pitera, K.; Jonsson, T. Accidents between freight vehicles and bicycles, with a focus on urban areas. Transp. Res. Procedia 2017, 25, 999-1007. [CrossRef]

94. Kaplan, S.; Vavatsoulas, K.; Prato, C.G. Aggravating and mitigating factors associated with cyclist injury severity in Denmark. J. Saf. Res. 2014, 50, 75-82. [CrossRef] [PubMed]

95. Kroyer, H.R.G. The relation between speed environment, age and injury outcome for bicyclists struck by a motorized vehicle-A comparison with pedestrians. Accid. Anal. Prev. 2015, 76, 57-63. [CrossRef] [PubMed]

96. Cheng, A.S.; Liu, K.P.; Tulliani, N. Relationship between driving-violation behaviours and risk perception in motorcycle accidents. Hong Kong J. Occup. Ther. 2015, 25, 32-38. [CrossRef]

97. Jama, H.H.; Grzebieta, R.H.; Friswell, R.; McIntosh, A.S. Characteristics of fatal motorcycle crashes into roadside safety barriers in Australia and New Zealand. Accid. Anal. Prev. 2011, 43, 652-660. [CrossRef] [PubMed]

98. Lucidi, F.; Giannini, A.M.; Sgalla, R.; Mallia, L.; Devoto, A.; Reichmann, S. Young novice driver subtypes: Relationship to driving violations, errors and lapses. Accid. Anal. Prev. 2010, 42, 1689-1696. [CrossRef] [PubMed]

(C) 2019 by the authors. Licensee MDPI, Basel, Switzerland. This article is an open access article distributed under the terms and conditions of the Creative Commons Attribution (CC BY) license (http://creativecommons.org/licenses/by/4.0/). 